Chirurgia (2017) 112: 193-207

No. 3, May - June

Copyright@ Celsius

http://dx.doi.org/10.21614/chirurgia.112.3.193

\title{
Current Management of Perihilar Cholangiocarcinoma and Future Perspectives
}

\author{
Heather L. Lewis', Amir A. Rahnemai-Azar², Mary Dillhoff', Carl R. Schmidt', Timothy M. Pawlik' \\ 'Department of Surgery, The Ohio State University Wexner Medical Center, Columbus, $\mathrm{OH}$ \\ ${ }^{2}$ Department of Surgery, University of Washington Medical Center, Seattle, WA
}

Corresponding author:

Timothy M. Pawlik, MD, MPH, PhD

Professor and Chair

The Urban Meyer III and Shelley

Meyer Chair for Cancer Research

Department of Surgery

Wexner Medical Center,

Ohio State University

395 W. 12th Ave., Suite 670,

Columbus, $\mathrm{OH}$

Email:Tim.Pawlik@osumc.edu
Received: 26.03.2017

Accepted: 18.04 .2017

\section{Rezumat}

Managementul actual al colangiocarcinomului perihilar și perspective

Colangiocarcinomul perihilar este cel mai des întâlnit tip de cancer al căilor biliare, asociat cu o mortalitate ridicată din cauza întârzierii prezentării la medic. Pentru stabilirea diagnosticului şi planificarea preoperatorie este nevoie de modalități imagistice cu secțiuni transversale de înaltă rezolutie. Deşi rezecția chirurgicală cu margini de rezecție negative dă speranța vindecării, doar un mic procent al pacienților pot beneficia de intervenție chirurgicală la momentul diagnosticului. Embolizarea venei porte şi decompresia căilor biliare au prioritate în cazul unor pacienți, înainte de intervenția chirurgicală. Transplantul hepatic combinat cu tratamentul neoadjuvant a avut rezultate foarte bune la pacienți selectați cu afecțiuni inoperabile, cu o rată de supraviețuire de 5 ani fără recidivă. Gemcitabina plus cisplatin constituie tratamentul chimioterapeutic de bază la pacienții cu colangiocarcinom perihilar metastatic inoperabil. Progresele recente în înțelegerea patogenezei moleculare a colangiocarcinomului au generat un interes ridicat în identificarea de tratamente inovatoare care au ca obiectiv căi moleculare cu rol cheie. În cele de față, prezentăm o trecere în revistă a principiilor actuale de management al pacienților cu colangiocarcinom perihilar.

Cuvinte cheie: cancerul căilor biliare, Klatskin, colangiocarcinom, colangiocarcinom extra-hepatic, management, colangiocarcinom perihilar, chirurgie 


\begin{abstract}
Perihilar cholangiocarcinoma is the most common type of biliary tract cancer and is associated with a high mortality, usually due to late presentation. High-resolution cross-sectional imaging modalities are necessary for diagnosis and preoperative planning. Although surgical resection with negative margins offers the only hope for cure, only a small subset of patients are amenable for surgery at the time of diagnosis. Portal vein embolization and biliary tract decompression are important in some patients prior to surgical resection. Liver transplantation in combination with neoadjuvant therapy has resulted in excellent 5-year recurrence-free survival rates in highly selected patients with inoperable disease. Gemcitabine plus cisplatin constitute the backbone of chemotherapy in patients with inoperable metastatic perihilar cholangiocarcinoma. Recent advances in understanding the molecular pathogenesis of CCA have created a growing interest in identifying novel therapies targeting key molecular pathways. Herein, we provide an overview of the most current principles of management of patients with perihilar cholangiocarcinoma.
\end{abstract}

Key words: biliary tract cancer, Klatskin, cholangiocarcinoma, extra-hepatic cholangiocarcinoma, management, perihilar cholangiocarcinoma, surgery

\section{Introduction}

Cholangiocarcinoma (CCA) is a diverse group of rare gastrointestinal malignancies arising from the biliary tract epithelium (1). CCA encompasses three distinct anatomic categories, namely intrahepatic (iCCA), perihilar (pCCA) and distal (dCCA) cholangiocarcinoma, all of which demonstrate different clinical, morphologic and epidemiologic features (Fig. $1 A, B)(2)$. The perihilar variant (pCCA) is the most common subtype (50-60\%) which arises from malignant proliferation of epithelial cells located between the second-degree bile ducts and the insertion of cystic duct into the common bile duct $(3,4)$. In 1957 , Dr. William Altemeier described the first series of three patients with hilar cholangiocarcinoma (5). However, Gerald Klatskin is more broadly recognized for his description of the unique features of CCA which occurs at the confluence of the left and right hepatic ducts (6). Hilar cholangiocarcinoma has since born the moniker of "Klatskin tumor".

Although surgical resection with negative margins remains the only potentially curative therapy, most patients do not have disease amenable to this treatment strategy at the time of diagnosis. More recently, advances in the understanding of the genetic landscape of CCA have introduced the potential for superior systemic therapeutic agents which may improve patient outcome. In this review, we provide an overview of the most current principles of management of patients with pCCA and how the understanding of the genetics of cholangiocarcinoma may influence future treatment algorithms.

\section{Epidemiology and Risk Factors}

Globally, CCA accounts for approximately three percent of all gastrointestinal malignancies $(7,8)$. The incidence and mortality rates of extrahepatic CCA are declining worldwide, while those of iCCA are rising. Like most cancers, the risk of CCA increases with age and the typically age of presentation is 60-70 years. There is a wide geographic disparity in incidence rate of CCA, perhaps related to variation in exposure to risk factors. Although the annual incidence rate of CCA in the United States is reported to be 1-2 cases per 100,000, this rate is notably higher in eastern Asian countries (8). For instance, Northeast Thailand has reported rates of $85 / 100,000$, most likely attributable to the high infection rates with the liver flukes Clonorchis sinensis (C. sinensis) and Opisthorchis viverrini ( $O$. vivverrini). Similar trends have been observed in China and Korea (9). Europe, as with other Western 
$\mathbf{A}$

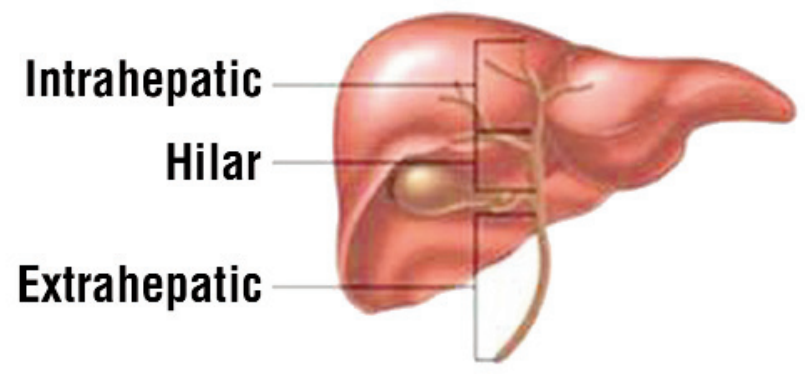

B
Mass-like

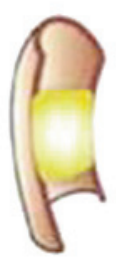

C
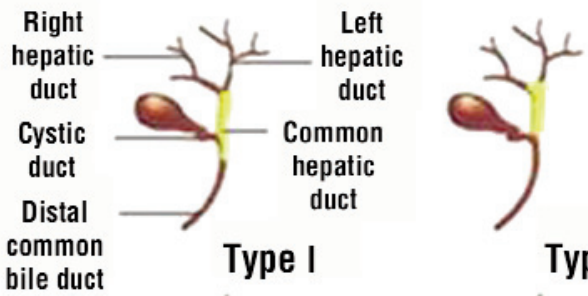

Periductal

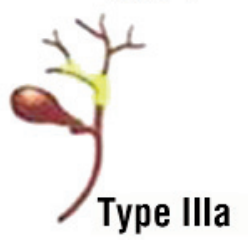

Type II
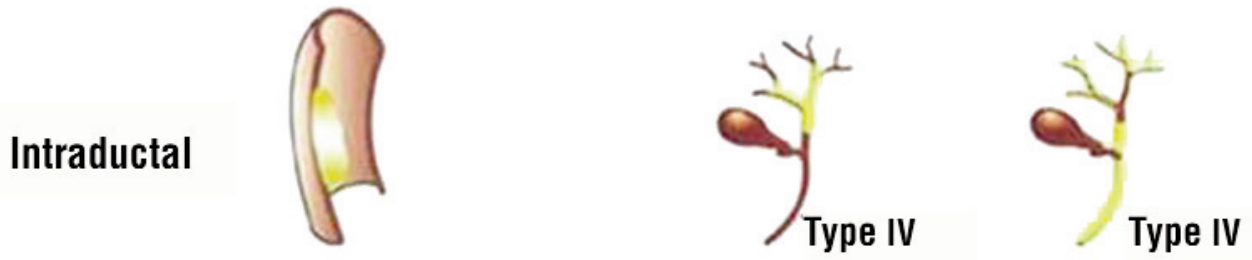

Figure 1. Classification of cholangiocarcinoma. (A) The classification of cholangiocarcinoma can be based on anatomic location: intrahepatic, hilar or extrahepatic; (B) Lesions can be further characterized as mass-like, periductal or intraductal; (C) Bismuth classification for hilar lesions (Bismuth and Corlette, 1975). Type I: Involvement of hepatic duct below the bifurcation, Type II: Involvement of bifurcation without invasion of second order ducts, Type IIla: Involvement of right sided ducts into second order, but with sparing of left second order ducts, Type IIIb: Involvement of left sided ducts into second order, but with sparing of right second order ducts, Type IV: Involvement of bilateral second order ducts and/or skip lesions

countries, report overall lower incidence rates, although there is some heterogeneity to these trends (10).

Although most cases of CCA occur sporadically, chronic inflammatory processes of the biliary tract, such as primary sclerosing cholangitis (PSC), hepatolithiasis, choledochocal cysts, Caroli's disease, and parasitic infestation with liver flukes are well-established risk factors. In Western countries, PSC is the most common predisposing condition, especially for pCCA (11). The lifetime risk of developing CCA in patients with PSC ranges between 5-40\%, with a possible association with duration of the disease (12-14). In contrast, infestation with the hepatobiliary flukes $O$. vivverrini and $C$. sinensisis the most commonly reported risk factor in Asian countries, especially in Southeast Asia as these parasites are endemic in these areas $(15,16)$. Both $O$. vivverrini and $C$. sinensis have been deemed by the International Agency for Research on Cancer as carcinogenic to humans based on their ability to increase the risk of CCA development (12). Other chronic liver infections, 
such as Hepatitis B (HBV) and Hepatitis C (HCV), have been studied in conjunction with the diagnosis of CCA in Asia, Europe, and the United States. However, no association with extrahepatic CCA and these infections has been well established, although in some studies intrahepatic CCA has been associated with HCV as well as with cirrhosis $(9,17-20)$. Choledochal cysts and Caroli's disease are rare congenital disorders reported to be associated with a 15$20 \%$ risk of development of malignant changes after the second decade of life $(21,22)$. Hence, the recommendation for surgical resection within the first decade of life is made for this patient population in order to diminish the risk of malignancy, although the risk does not ever return to that of the general population (23).

\section{Histopathology and Molecular Pathogenesis}

The vast majority of pCCAs are adenocarcinomas $(>90 \%)$ with rare occurrence of other histologic subtypes such as squamous cell carcinoma and signet-ring carcinoma (2426). Further differentiation of pCCA can be made based on three subtypes, sclerosing $(>70 \%)$, nodular $(20 \%)$ and papillary $(5-10 \%)$ $(26,27)$. A dense desmoplastic reaction is characteristic of the sclerosing subtype, which may complicate the success of preoperative diagnosis by tissue sampling and cytology as malignant cells may be found in clumps mixed within the inflammatory milieu of cells, potentiating the risk for false negative results (28). Immunohistochemical (IHC) staining is most frequently done for cytokeratins (CK7 and CK19), carcinoembryonic antigen, and mucins, although no pathognomonic stain is available for malignancies of biliary tract origin (28). Systematic reviews and meta-analyses of IHC performed in resected CCA has demonstrated an association of the patients' postoperative survival with markers for fascin, VEGF-A, c-erbB-2, EGFR, MUC1, MUC4, p38delta and p27. Marker expression may also vary between iCCA and extrahepatic CCA, which further confirms the biologically distinct behavior of these lesions (29-31).

While nodal metastasis typically occurs via perineural and periductal lymphatic channels and distal metastasis occur via the hematogenous route, local progression of pCCA usually occurs through intrahepatic ductal extension. Regional (hilar, cystic duct, choledochal, portal, hepatic artery) lymphadenopathy is common and may be considered a relative contraindication for aggressive surgical therapy because of poor prognosis $(3,32,33)$. Lymph node involvement distal to the hepatoduodenal ligament is considered distant disease.

The cellular origin of pCCA is postulated to be in the biliary epithelium and peribiliary glands. Recent studies have demonstrated that gene expression and IHC profiles of mucinproducing pCCAs are similar to the cholangiocytes lining perihilar and large bile ducts (34). The chronic inflammatory state which is thought to contribute to tumor development works through the release of inflammatory cytokines that induce oxidative stress with resultant DNA damage. These cytokines may also create an immune-suppressive environment that promotes tumor cell survival and proliferation by blockade of the apoptosis normally induced by DNA damage (35). Epidermal growth factor receptor (EGFR), along with ERBB2, has also been implicated in cholangiocarcinogenesis. The overexpression of these receptors is associated with activation and up-regulation of growth signals. Additionally, bile acids have been demonstrated to further activate EGFR and increase the expression of oxidative agents (34).

The role of chromosomal aberrations in cholangiocarcinogenesis has been most well studied in the setting of iCCA. Patterns of genomic change appear to be related to the differences in etiology and ethnicity (36). Gains and losses in chromosomal regions containing oncogenes and tumor suppressor genes (e.g. EGFR, ERBB2, MAP2K2/MEK) have been correlated with the development of CCA (37, 38). Most somatic mutations occur at a low frequency. IDH 1/2 mutations, one of the most frequently detected mutations in CCA pathogenesis, are more common in iCCA compared with extrahepatic CCA ( $22 \%$ vs. $7 \%$, respectively; $p=0.03)(39,40)$. Notably, the somatic 
mutations found in patients with $O$. viverrini related CCA (e.g. MLL3, ROBO2, RNF43, PEG3, and GNAS) were significantly different than non-infectious CCA (e.g. BAP1, IDH1 and IDH2) (30,31). TP53 and KRAS mutations are frequently seen in CCA patients from all geographic regions including Asia, Europe and the United States. Multiple pathways and genomic alterations are known to be aberrant in CCA include wnt signaling, cytokine signaling, TGF-beta signaling, MAPK signaling, AKT/ PI3K signaling, genomic stability, cell cycle control and epigenetic regulation (37).

\section{Clinical Manifestation and Diagnosis}

The clinical features of pCCA depend on stage and location of tumor $(4,41)$. The majority of patients present at advanced stage with obstructive jaundice (41). However, in patients with incomplete obstruction of the right or left hepatic duct or segmental ducts, jaundice may not be the presenting feature. Early symptoms are nonspecific and may include abdominal pain, weight loss and pruritus. Some patients develop a hypertrophy- atrophy complex secondary to ipsilateral vascular encasement, which manifests as the palpable prominence of one hepatic lobe $(42,43)$. In the case of intraductal papillary tumors, intermittent jaundice may be a presenting feature (41).

Initial work-up of obstructive jaundice is comprised of serum laboratory values which usually lack a high specificity. While elevated serum alkaline phosphatase (ALP) and bilirubin (Bil) levels are commonly observed in pCCA patients, incomplete obstruction of the right or left hepatic ducts may lead to isolated elevation of ALP $(41,44,45)$. Derangement of liver transaminases and prothrombin time/ international normalized ratio (PT/INR) usually occurs in the setting of longstanding biliary obstruction and/or cholestatic hepatocellular injury (45). Serum carbohydrate antigen 19-9 (CA 19-9) and carcinoembryonic angigen (CEA) levels may be elevated as well but also lack specificity. Of note, current United Network for Organ Sharing (UNOS) policy in patients being considered for transplantation uses a cutoff value of CA 19-9 $\geq 100$ U/ML for surveillance of CCA in patients with PSC to suspect recurrence, although higher values of CA $19-9 \geq 129 \mathrm{U} / \mathrm{ML}$ have been used by some investigators to increase specificity $(46,47)$.

High quality cross sectional imaging plays a key role in the diagnosis and pre-operative work-up of pCCA (Table 1). High-resolution contrast-enhanced multidetector computed tomography (MDCT) and magnetic resonance imaging / magnetic resonance cholangio-

Table 1. Imaging modalities for diagnosis/staging of cholangiocarcinoma

\begin{tabular}{|c|c|c|c|}
\hline Modality & Benefits & Drawbacks & Special Information \\
\hline US & $\begin{array}{l}\text { - No need for IV contrast } \\
\text { - Good visualization of bile ducts } \\
\text { - Can be tailored to answer specific } \\
\text { questions }\end{array}$ & $\begin{array}{l}\text { - Operator dependent } \\
\text { - Not specific for diagnosis of tumors } \\
\text { - May be limited in obese patients }\end{array}$ & $\begin{array}{l}\text { - Doppler US can demonstrate } \\
\text { flow in vessels and possibly } \\
\text { trouble shoot questions regarding } \\
\text { vascular involvement }\end{array}$ \\
\hline CT & $\begin{array}{l}\text { - Highly reproducible from } \\
\text { center-to-center } \\
\text { - High spatial resolution for anatomic } \\
\text { delineation } \\
\text { - Fast and available } \\
\text { - Can perform whole body staging }\end{array}$ & $\begin{array}{l}\text { - Not as specific as MRI for liver } \\
\text { lesion diagnosis } \\
\text { - Not as helpful for delineating bile } \\
\text { duct anatomy }\end{array}$ & $\begin{array}{l}\text { - CT contrast is nephrotoxic and } \\
\text { should be avoided in patients } \\
\text { with renal failure or acute renal } \\
\text { dysfunction }\end{array}$ \\
\hline MRI/MRCP & $\begin{array}{l}\text { - Best non-invasive modality for bile } \\
\text { duct } \\
\text { - Most sensitive/specific modality for } \\
\text { diagnosis of CC } \\
\text { - Most specific for liver lesion } \\
\text { characterization }\end{array}$ & $\begin{array}{l}\text { - Motion dependent, poor images } \\
\text { in patients who cannot follow } \\
\text { breath-hold commands } \\
\text { - variable image quality from } \\
\text { center-to-center }\end{array}$ & $\begin{array}{l}\text { - There are some contraindications } \\
\text { to MRI (certain implanted devices, } \\
\text { claustrophobia) } \\
\text { - Gadolinium contrast is not } \\
\text { nephrotoxic but should be avoided } \\
\text { in patients with severe renal } \\
\text { dysfunction }\end{array}$ \\
\hline
\end{tabular}


pancreatography (MRI/MRCP) are widely accepted as the most accurate modalities for diagnosis of pCCA, assessment of tumor ductal extension and involvement of adjacent vital structures (Fig. 2) $(48,49)$. When both are well performed, the accuracy of MRI and CT in predicting resectability exceeds $75 \%$ (49). Of note, imaging studies should be obtained prior to any biliary tract intervention as the diagnostic and staging accuracy of both modalities significantly diminish after biliary stent placement. Endoscopic methods such as endoscopic ultrasound scan (EUS), intra-ductal ultrasound (IDUS), and cholangioscopy are used selectively in diagnosing and staging of pCCA.

Tissue diagnosis prior to surgical resection or liver transplantation is not required in patients with high clinical suspicion for pCCA (49). Some studies have demonstrated that clinical evaluation accurately predicted the presence of malignancy in approximately $90 \%$ of the patients (49). However, pathologic confirmation is preferred before treatment with chemo- or radio- therapy, or when it is felt that the patient may benefit from neoadjuvant treatment (e.g. presence of suspicious regional lymphadenopathy). When considering a tissue diagnosis via brush cytology, both endoscopic retrograde cholangiopancreatography (ERCP) and percutaneous transhepatic cholangiography (PTC) have similar sensitivity and specificity. Despite the high specificity of ERCP
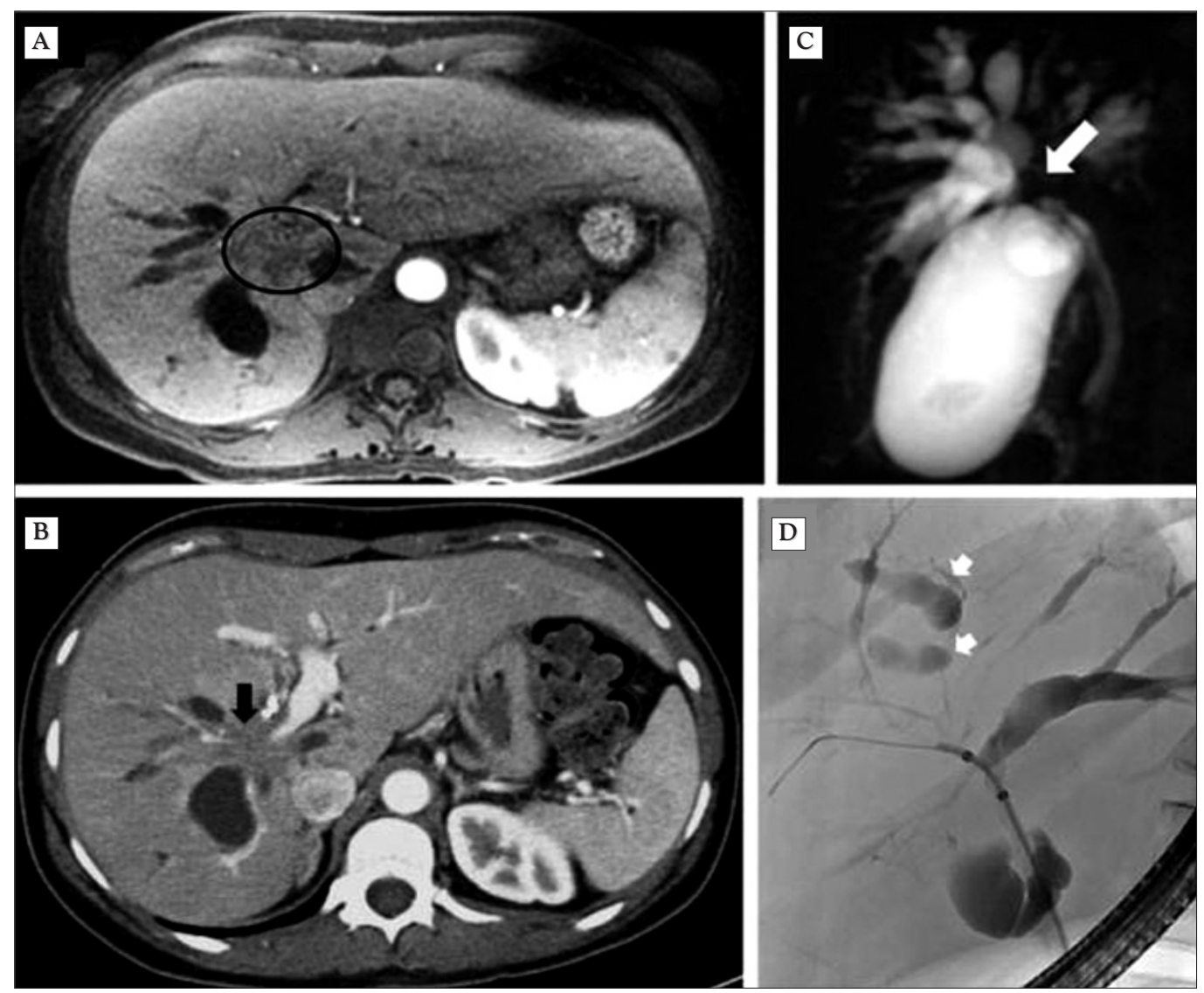

Figure 2. Diagnostic modalities used for cholangiocarcinoma. (A) MRI image of a pCCA mass (outlined in circle). (B) CT image of a pCCA mass with right portal vein encasement (indicated by black arrow). (C) MRCP image of common hepatic duct involvement by tumor (indicated by white arrow). (D) ERC image depicting excluded segmental ducts (white arrows) in a patient with a hilar biliary stricture extending into the right main hepatic duct. CT, computed tomography; ERC, endoscopic retrograde cholangiography; MRCP, magnetic resonance cholangiopancreatography; MRI, magnetic resonance imaging; pCCA, perihilar cholangiocarcinoma 
with brush cytology for the diagnosis of CCA, especially dCCA, its sensitivity is much lower (18\% - 60\%), mainly due to low cellularity and concomitant desmoplastic reaction. New cytological techniques such as DIA (digital image analysis) and FISH (fluorescence in-situ hybridization) can be applied to increase the diagnostic yield of ERCP and brush cytology (50-52). EUS with fine needle aspiration is useful in detection of suspicious regional lymph node involvement (53).

\section{Classification/Staging}

Classification of tumors provides a framework within which prognostic and strategic algorithms may be constructed. Several classification systems have been introduced in an effort to aid this process in patients with pCCA (32, 54-56).

\section{A. Bismuth-Corlette Classification}

One of the initial steps in the evaluation of pCCA is defining anatomic location and ductal extent of the tumor, essential elements for operative planning. The Bismuth-Corlette classification is perhaps the most widely adopted system, which places lesions into one of four categories based on the relationship to the confluence of the right and left hepatic ducts (Fig. 1C)(54). The descriptive classification can then be correlated with the resection method which may be required for complete extirpation of the tumor and establishment of biliary tract continuity (Table 2).

\section{B. American Joint Committee on Cancer (AJCC) Classification}

In 2010, considering the distinct biologic and clinical behavior of CCA subtypes, the $7^{\text {th }}$ edition of the AJCC provided a separate TNM classification for pCCA (32). In this system, the primary tumor $(\mathrm{T})$ was assessed based on its relationship to surrounding structures. Specifically, T1: confined to the bile duct, T2a/ T2b: invading surrounding adipose tissue beyond the duct or into the hepatic parenchyma, T3: invading unilateral vascular structures (portal vein or hepatic artery), or T4: invading more distal vascular structures (portal vein, hepatic artery) and/or biliary radicals. Because the bile duct lacks discrete boundaries, T-classification criteria present some challenges, and some authors have suggested that tumor depth might be a more accurate predictor of long-term outcome (57). Nodal assessment is based on regional nodal involvement versus more distant. Notably, number of lymph nodes with metastasis may be a more important prognostic factor, as opposed to the location from which they are retrieved $(33,58,59)$. Metastasis is assessed according to the absence or presence of distant disease. While simple, the utility of the

Table 2. The Bismuth-Corlette classification system is widely utilized for hilar cholangiocarcinoma, and provides categorization of lesions based on anatomic location as it pertains to the confluence of the right and left hepatic ducts. Surgical intervention may be guided by categorization

\begin{tabular}{ll}
\hline Bismuth-Corlette Classification & Surgical Intervention \\
\hline $\begin{array}{l}\text { Type I: hilar CCA which is found at the level of the cystic duct, } \\
\text { but below the confluence of the right and left hepatic ducts }\end{array}$ & $\begin{array}{l}\text { Extrahepatic biliary duct resection, cholecystectomy, regional } \\
\text { lymphadenectomy, biliary reconstruction, }+/- \text { pancreatico- } \\
\text { duodenectomy depending on distal extent }\end{array}$ \\
$\begin{array}{l}\text { Type II: hilar CCA which is found at the bifurcation of right and } \\
\text { left hepatic ducts }\end{array}$ & $\begin{array}{l}\text { If proximal extent is permissive, procedure as annotated for type I } \\
\text { Type IIla: hilar CCA which is found at the bifurcation with }\end{array}$ \\
$\begin{array}{l}\text { extension into the right hepatic duct } \\
\begin{array}{l}\text { Type IIIb: hilar CCA which is found at the bifurcation with } \\
\text { extension into the left hepatic duct }\end{array}\end{array}$ \\
$\begin{array}{l}\text { Type IV: hilar CCA which is found extending into both the } \\
\text { right and left hepatic ducts, or, multicentric disease }\end{array}$ \\
\hline
\end{tabular}


TNM staging system is most relevant in the post-operative setting, after surgical extirpation and for final pathologic determination, and may have lower prognostic implications.

\section{Memorial Sloan-Kettering Cancer Center (MSKCC) Classification}

The MSKCC classification attempted to create a system which was able to accurately predict resectability and subsequent outcomes. Jarnagin et al. evaluated 225 patients with pCCA who were seen and followed over a nine-year period of time. Through this experience, they introduced a discrete staging system in which the tumor involvement was assessed based on local extension of the tumor, location of bile duct involvement, and the presence of portal vein invasion and hepatic lobar atrophy (55). Further analysis comparing different staging systems has demonstrated good correlation of the MSKCC classification with overall survival of patients undergoing surgical resection (60,61). Recently, prognostic nomograms have been developed to aid with prediction of disease specific survival following curativeintent surgery, although their clinical application requires further validation $(62,63)$.

\section{International Guidelines}

More recently, an expert consensus proposed a new classification system in an effort to achieve an internationally accepted staging system which was simple, reproducible, and easily applicable. Deoliveira et al. introduced criteria in which the bile duct, portal vein and hepatic artery are assigned a label based on the anatomic involvement of the tumor. The tumor is then additionally classified by the size and histologic subtype. Lymph node involvement and distant metastasis staging is similar to TNM classification. Additionally, the liver remnant volume and underlying hepatic parenchymal integrity are also taken into consideration (56). Further study of these guidelines through multi-center review is needed for optimal validation.

\section{Surgical Resection}

\section{A. Criteria to Determine Resectability}

Surgical resection is planned based on the ability to achieve $\mathrm{R} 0$ resection (resection with negative microscopic margins), while maintaining adequate liver remnant, vascular inflow/ outflow, and biliary drainage. Determination of surgical resectability pre-operatively continues to be a challenge and requires multidisciplinary and multimodality evaluation. Generally, the presence of severe underlying medical $\mathrm{co}^{-}$ morbidities, distant metastasis, involvement of major vascular structures not amenable to reconstruction, bilateral segmental ductal involvement, unilateral segmental ductal extension with contralateral vascular inflow involvement, and inadequate calculated future liver remnant (FLR) are generally considered contraindications to surgical resection (49).

\section{B. Surgical Resection Technique}

Surgical resection with negative margins offers the only chance for potential cure (Fig. 3). However, only a small subset of patients will be eligible for surgical resection at the time of diagnosis. Furthermore, $20-50 \%$ of patients thought to benefit from surgical resection based on preoperative work-up are found to have unresectable disease at the time of exploration $(55,60,64)$. Therefore, several studies have suggested the potential benefit of staging laparoscopy as a means of identifying locally advanced or metastatic disease not amenable for surgical resection $(65,66)$. However, a more recent study of almost two hundred patients with pCCA demonstrated a decreased overall diagnostic yield and accuracy of staging laparoscopy, mainly due to improved imaging techniques (67). Overall, surgical resectability rates range from $35-94 \%$ in large series, with a wide range of margin negativity (14-78\%), suggesting wide variation in surgeon and institutional approach $(4,55,68,69)$. In tumors with extension into the caudate lobe, central location, or involvement of the left hepatic duct, caudate resection is recommended $(70,71)$. 


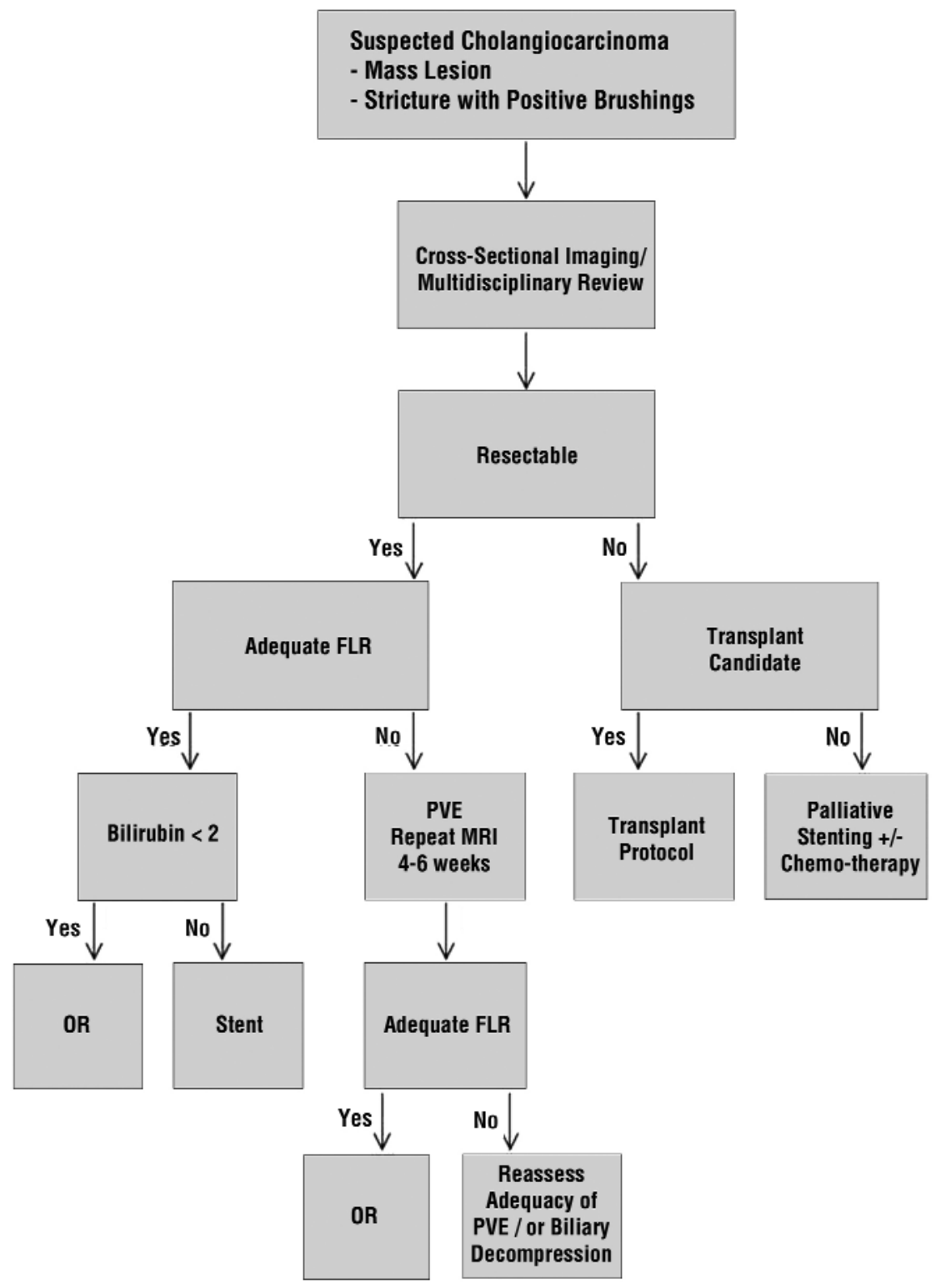

Figure 3. Perihilar cholangiocarcinoma management algorithm

Although controversial, the role of vascular resection and reconstruction (e.g. portal vein and/or hepatic artery) has been advocated by an increasing number of surgeons. Review of patients undergoing curative-intent resection for pCCA identified from a large international, multi-institutional database demonstrated that portal vein resection was not associated with worse outcome and should be undertaken when necessary to achieve an $\mathrm{R} 0$ resection (72). However, the decision for vascular resection must be made on an individual patient basis
(73). Patients who successfully undergo an R0 surgical resection have a median survival of which ranges from 27 to 58 months with a 5 -year survival rate of $27 \%$ to $45 \%$. These numbers drop significantly to $12-21$ months and $0-23 \%$ in patients with positive resection margins (55,74-76). R0 resection, well-defined histology, concomitant hepatic resection, and absence of lymph node metastasis are the primary factors associated with long-term survival (3,33,77-79). 


\section{Pre-operative Optimization}

\section{Portal Vein Embolization (PVE)}

Many patients with pCCA will present with advanced disease and large tumors that require major hepatic resection. A patient with a normal underlying liver requires at least a $20 \%$ FLR to prevent postoperative liver failure. The percentage increases to $30 \%$ for patients who have steatosis or steatohepatitis and further ascends to $40 \%$ in patients with underlying cirrhosis $(80,81)$. For patients with pCCA who do not meet FLR requirements, additional preoperative procedures to induce hypertrophy of the FLR such PVE may be of benefit (80-82). Postoperative morbidity and mortality for patients who undergo PVE is comparable to those patients who had an adequate FLR prior to surgery (83).

\section{Biliary Decompression}

The role and route of preoperative biliary drainage in jaundiced patients remains controversial. Biliary drainage is indicated in septic patients with suspected cholangitis, patients undergoing PVE, or patients with planned preoperative anti-neoplastic therapy. Biliary decompression may also help to improve coagulopathy, ameliorate renal insufficiency associated with hepatic failure, or provide symptomatic relief (e.g., pruritus) (84). Proponents of preoperative biliary drainage advocate that it provides improved hepatic function, optimization of nutritional parameters, and reduces the risk of cholangitis and post-operative liver failure (85, 86). However, in a recent multicenter retrospective study, preoperative biliary drainage was not associated with improved postoperative outcomes (87). In contrast, opponents believe that biliary drainage increases the risk of drain track tumor seeding, cholangitis, pancreatitis, perioperative infections, and also may lengthen post-operative hospital stay (88). In general, biliary drainage should be strongly considered for any patient with a bilirubin $>6-7 \mathrm{mg} / \mathrm{dl}-$ especially in patients with an anticipated small liver remnant.

Due to a reported $1.4-5 \%$ risk of tumor seeding of the drain track with percutaneous biliary drainage, endoscopic retrograde cholangiopancreatography (ERCP) is advocated by some as the preferred method for stent placement. However, endoscopic stent occlusion rates have been reported as high as $60 \%$. Additionally, unsuccessful attempts with endoscopic decompression place patients at risk for contamination of undrained areas due to retrograde injection of contrast. Furthermore, percutaneous transhepatic cholangiography (PTC) can provide much better delineation of the extent of biliary tract involvement for preoperative planning (49). Alternate preoperative drainage methods such as nasobiliary drainage are under ongoing investigation (89).

\section{Neoadjuvant Therapy}

The role of neoadjuvant therapy in the management of pCCA is not well defined. A relative paucity of large prospective studies confounds the ability to make a well informed conclusion. The current data in the setting of surgical resection is limited to a few small case series and retrospective studies with inconsistent success rates in achieving $\mathrm{R} 0$ resection (90). However, the role of neoadjuvant chemoradiation in combination with liver transplantation is better studied (91-93). Although regimens may have some variation among institutions, typically 4000-4500 cGy of externalbeam radiation is given in conjunction with 5 -fluorouracil chemosensitization, followed by endoluminal brachytherapy with iridium wires. Maintenance capecitabine is administered while patients await transplantation. Up to one-third of patients who initiate neoadjuvant treatment are unable to complete therapy due to toxicity. Additionally, if evidence of disease progression or distant metastasis develops while the patient is receiving neoadjuvant treatment, these factors preclude liver transplantation $(91,94)$.

\section{E. Adjuvant Therapy}

High rates of loco-regional recurrence or distant metastases following resection of pCCA provide the main rationale for adjuvant therapies. Due to rarity of the tumor, data on 
adjuvant therapy for pCCA are mainly derived from studies that examine a broad category of patients with advanced biliary tract cancers. Takada et al. evaluated the role of postoperative chemotherapy with 5-FU, doxorubicin, and mitomycin in 508 patients with resected pancreatobiliary malignancy and failed to show any statistically significant survival benefit (95). Five year survival rates were similar when the data was stratified to study the subgroup of 118 patients with bile duct cancer ( $26.7 \%$ vs $24.1 \%$, treatment group vs. control group; $p=N S)$. In the European Study Group of Pancreatic Cancer trial (ESPAC)-3, the use of adjuvant therapy was not associated with a survival advantage in all patients with peri-ampullary malignancies or in the subset of patients with bile duct cancer (96). However, a meta-analysis of data including 6712 patients with biliary tract cancer who underwent curative-intent surgery revealed that chemo $^{-}$and chemoradio-therapy are associated with better survival than radiation therapy alone $(p=0.02)$. Furthermore, patients with node-positive and margin-positive disease appeared to derive the clearest survival benefit from adjuvant therapy (97).

According to National Comprehensive Cancer Network (NCCN) guidelines for extra-hepatic CCA, adjuvant treatment with fluoropyrimidinebased chemoradiotherapy followed by additional fluoropyrimidine or gemcitabine chemotherapy should be considered for patients after resection with gross residual disease (R2), positive microscopic margins (R1) or regional lymph node involvement. For patients with negative nodes and margins after resection or with carcinoma in-situ at the margin, observation is reasonable however NCCN guidelines also support adjuvant therapy for these patients.

\section{Transplantation}

Despite initially disappointing results, the introduction of a more rigorous pre-transplant protocol by the Mayo clinic, including improved patient selection criteria, and the addition of neoadjuvant therapy, has now resulted in excellent 5-year recurrence-free survival rates of 65-70\% (91-93) after transplant for pCCA. The Mayo Clinic selection criteria for pCCA includes: 1) diagnosis via positive biliary biopsy /cytology for adenocarcinoma or malignant appearing stricture with CA $19-9>100 \mathrm{U} / \mathrm{mL}$ without bacterial cholangitis, 2) tumor size $<3$ $\mathrm{cm}, 3)$ absence of distant metastasis on imaging, and 4) negative EUS-FNA or regional lymph nodes and negative staging laparotomy/handassisted laparoscopy with biopsy of regional lymph nodes (93). Patients are excluded if they have mass lesion $>3 \mathrm{~cm}$ radial diameter, any evidence of extrahepatic disease or regional lymph node involvement, history of previous malignancy (excluding skin or cervical cancer), prior abdominal radiotherapy, uncontrolled infection, previous attempt at surgical resection with violation of tumor plane, or a medical condition that otherwise precludes transplant $(92,93,98)$.

\section{Management of Metastatic Disease}

Data on systemic therapy for pCCA are scarce and are typically derived from studies that examine "all comer" advanced biliary tract cancers. The utility of gemcitabine in the treatment for hepato-pancreatico-biliary tumors has been increasingly recognized. In 2010, Valle et al. demonstrated in a phase III (ABC-02) study of 410 patients with locally advanced or metastatic biliary tract cancers (241 CCA) that treatment with gemcitabine plus cisplatin was associated with a survival advantage over gemcitabine alone group (11.7 months vs. 8.1 months, respectively; $p=<0.001$ ) without additional toxicity (99). Progression-free survival (PFS) also was improved (median OS 8.0 mo vs. 5.0 mo, combination therapy group vs gemcitabine-only, $p=<$ 0.001). Follow up studies utilizing the same regimen have validated these results $(100,101)$.

Recent advances in understanding molecular pathogenesis of CCA have created a growing interest in identifying novel therapies targeting key molecular pathways (38). Considering the role of EGFR in the pathogenesis of CCA, EGFR inhibitors have been proposed as potential chemotherapeutic agents. However, despite initial favorable results, subsequent randomized 
trials have failed to confirm the clinical benefit of EGFR inhibitors $(102,103)$. Similarly, combination chemotherapy with panitumumab, another drug in the anti-EGFR antibody class, was not associated with a survival benefit (105). In a phase III study, Lee et al. reported that patients with advanced biliary tract cancers who were treated with erlotinib plus gemcitabine and oxaliplatin had a higher objective response rate compared to patients treated with chemotherapy alone $(p=0 \cdot 005)(106)$. However, there was no difference in median PFS (5.8 months in combination therapy vs. 4.2 in chemotherapy alone; $\mathrm{p}=0.087$ ) or median OS (9.5 months for each arm). In a subgroup analysis of 84 patients with CCA, the addition of erlotinib to chemotherapy was associated with a prolonged median PFS of 5.9 months versus 3 months in chemotherapy alone group $(\mathrm{p}=0 \cdot 049)(106)$. In a randomized study of 122 patients with advanced biliary tract cancers who were stratified by KRAS status, the combination of gemcitabine plus oxaliplatin (GEMOX) and cetuximab was associated with improved median progression-free-survival (PFS) (6.7 months) compared with chemotherapy only (4.1 months, $p=0.05)(102)$, an improvement which was independent of KRAS mutation status. Median OS was, however, similar between the two groups (10.6 months vs. 9.8 months; $p=0.91)(102)$. The addition of cetuximab to the combination regimen of gemcitabine, capecitabine and oxaliplatin did not improve PFS or OS (104). The phase II study ABC-03 investigating the clinical benefit of adding a VEGF inhibitor (cediranib) to cisplatin and gemcitabine was discouraging, with a median PFS in the cediranib group of 8.0 months vs 7.4 months in the placebo arm (HR 0.93; $\mathrm{p}=0.72)(107)$.

The MAPK/ERK pathway and its different substrates are frequently deregulated in CCA and other biliary tract cancers, making them attractive targets for molecular therapy. The efficacy of MEK inhibition has been investigated in management of patients with advanced biliary tract cancers. In a phase II trial of 28 patients with metastatic biliary tract cancers, selumetinib, a MEK1/2 inhibitor, produced an objective response in 3 participants and maintained stable disease in an additional 17 patients (108). In this cohort, only one patient experienced grade 4 toxicity and the median PFS and OS were 3.7 months and 9.8 months, respectively. Bridgewater et al. recently released the results of the $\mathrm{ABC}-04$ study, a phase $\mathrm{Ib}$ trial that added selumetinib to cisplatin and gemcitabine (109). Of the 8 patients who were assessable for objective response, 1 had a complete response, 1 had a partial response and 6 maintained stable diseases. The median PFS was 6.4 months and grade 3/4 selumetinib-associated toxicities occurred in $25 \%$ of patients. Currently, trametinib is being studied in an ongoing National Cancer Institute phase II trial evaluating the role of this single agent MEK inhibitor versus 5-FU or capecitabine for non-resectable advanced biliary cancers (ClinicalTrials.gov identifiers: NCT02042443).

AG-120 (IDH 1 inhibitor) and AG-221 (IDH 2 inhibitor) are two agents under investigation in phase I trials for patients with advanced solid tumors including CCA (ClinicalTrials.gov identifiers: NCT02073994 and NCT02273739, respectively). The FGFR2 signaling pathway may have therapeutic implications for CCA as well $(78,79)$. Pazopanib, a pan-FGFR inhibitor, is currently being evaluated in the setting of unresectable or metastatic biliary tract cancers in a phase II trial (ClinicalTrials.gov identifiers: NCT01855724).

Ongoing phase III trials may impact current practice patterns. The ABC-06 trial in the United Kingdom seeks to assess the efficacy of mFOLFOX (modified 5-FU, oxaliplatin, folinic acid) with active symptom control versus active symptom control alone in patients with metastatic disease who have failed first line therapy with gemcitabine and cisplatin (NCT01926236). Several other trials in Europe also are evaluating the use of adjuvant gemcitabine plus oxaliplatin or cisplatin (Germany, ACTOCCA-1, NCT02170090 and France, NCT01313377), as well as the role of concurrent chemoradiotherapy with adjuvant chemotherapy alone (NCT02798510). Additionally, the role of capecitabine in the adjuvant setting is being evaluated in the United Kingdom (NCT00363584). 


\section{Conclusion}

pCCA is a rare group of gastrointestinal malignancies with high fatality. The diagnosis and treatment of pCCA is often challenging and the majority of patients typically present at advanced stage when surgery is not recommended. Therefore, there is an urgent need for identification of novel diagnostic biomarkers that help in early diagnosis as well as screening of high-risk patients. Furthermore, conventional chemotherapy has demonstrated limited benefit in the management of unresectable or metastatic pCCA. New advances in genomic profiling have contributed to a better understanding of the landscape of molecular alterations in CCA and offer hope for the development of novel targeted therapies. Future studies should continue to focus on targeting deregulated signaling pathways with the goal of personalizing treatment for patients with pCCA.

\section{Funding details}

This research did not receive any specific grant from funding agencies in the public, commercial, or not-for-profit sectors.

\section{Disclosure statement}

Authors do not have any conflict of interests to disclose.

\section{References}

1. Siegel RL, Miller KD, Jemal A. Cancer statistics, 2016. CA Cancer J Clin. 2016;66(1):7-30.

2. Razumilava N, Gores GJ. Cholangiocarcinoma. Lancet. 2014; 383(9935):2168-79.

3. DeOliveira ML, Cunningham SC, Cameron JL, Kamangar F, Winter $\mathrm{JM}$, Lillemoe KD, et al. Cholangiocarcinoma: thirty-one-year experience with 564 patients at a single institution. Ann Surg. 2007;245(5):755-62.

4. Nakeeb A, Pitt HA, Sohn TA, Coleman J, Abrams RA, Piantadosi S, et al. Cholangiocarcinoma. A spectrum of intrahepatic, perihilar, and distal tumors. Ann Surg. 1996;224(4):463-73; discussion 73-5.

5. Altemeier WA, Gall EA, Zinninger MM, Hoxworth PI. Sclerosing carcinoma of the major intrahepatic bile ducts. AMA Arch Surg. 1957;75(3):450-60; discussion 60-1.

6. Klatskin G. Adenocarcinoma of the Hepatic Duct at Its Bifurcation within the Porta Hepatis. An Unusual Tumor with Distinctive Clinical and Pathological Features. Am J Med. 1965;38:241-56.

7. Vauthey JN, Blumgart LH. Recent advances in the management of cholangiocarcinomas. Semin Liver Dis. 1994;14(2):109-14.

8. Everhart JE, Ruhl CE. Burden of digestive diseases in the United States Part III: Liver, biliary tract, and pancreas. Gastroenterology. 2009:136(4):1134-44.

9. Shin HR, Oh JK, Masuyer E, Curado MP, Bouvard V, Fang YY, et al.
Epidemiology of cholangiocarcinoma: an update focusing on risk factors. Cancer Sci. 2010;101(3):579-85.

10. Khan SA, Toledano MB, Taylor-Robinson SD. Epidemiology, risk factors, and pathogenesis of cholangiocarcinoma. HPB (Oxford). 2008:10(2):77-82.

11. Welzel TM, Graubard BI, El-Serag HB, Shaib YH, Hsing AW, Davila $\mathrm{JA}$, et al. Risk factors for intrahepatic and extrahepatic cholangiocarcinoma in the United States: a population-based case-control study. ClinGastroenterolHepatol. 2007;5(10):1221-8.

12. Tyson GL, El-Serag HB. Risk factors for cholangiocarcinoma. Hepatology. 2011;54(1):173-84

13. Burak K, Angulo P, Pasha TM, Egan K, Petz J, Lindor KD. Incidence and risk factors for cholangiocarcinoma in primary sclerosing cholangitis. Am J Gastroenterol. 2004;99(3):523-6.

14. deGroen PC. Cholangiocarcinoma in primary sclerosing cholangitis: who is at risk and how do we screen? Hepatology. 2000;31(1):247-8.

15. Choi D, Lim JH, Lee KT, Lee JK, Choi SH, Heo JS, et al. Cholangiocarcinoma and Clonorchissinensis infection: a casecontrol study in Korea. J Hepatol. 2006;44(6):1066-73.

16. Kaewpitoon N, Kaewpitoon SJ, Pengsaa P, Sripa B. Opisthorchis viverrini: the carcinogenic human liver fluke. World J Gastroenterol. 2008;14(5):666-74

17. Donato F, Gelatti U, Tagger A, Favret M, Ribero ML, Callea F, et al. Intrahepatic cholangiocarcinoma and hepatitis $C$ and $B$ virus infection, alcohol intake, and hepatolithiasis: a case-control study in Italy. Cancer Causes Control. 2001;12(10):959-64.

18. Zhou YM, Yin ZF, Yang JM, Li B, Shao WY, Xu F, et al. Risk factors for intrahepatic cholangiocarcinoma: a case-control study in China. World J Gastroenterol. 2008;14(4):632-5.

19. Shaib YH, El-Serag HB, Davila JA, Morgan R, McGlynn KA. Risk factors of intrahepatic cholangiocarcinoma in the United States: a case-control study. Gastroenterology. 2005;128(3):620-6.

20. Shaib YH, El-Serag HB, Nooka AK, Thomas M, Brown TD, Patt YZ, et al. Risk factors for intrahepatic and extrahepatic cholangiocarcinoma: a hospital-based case-control study. Am J Gastroenterol. 2007:102(5):1016-21.

21. Lipsett PA, Pitt HA, Colombani PM, Boitnott JK, Cameron JL. Choledochal cyst disease.A changing pattern of presentation. Ann Surg. 1994;220(5):644-52.

22. Scott J, Shousha S, Thomas HC, Sherlock S. Bile duct carcinoma: a late complication of congenital hepatic fibrosis. Case report and review of literature. Am J Gastroenterol. 1980;73(2):113-9.

23. Kobayashi S, Asano T, Yamasaki M, Kenmochi T, Nakagohri T, Ochiai T. Risk of bile duct carcinogenesis after excision of extrahepatic bile ducts in pancreaticobiliarymaljunction. Surgery. 1999;126(5):939-44.

24. Abbas R, Willis J, Kinsella T, Siegel C, Sanabria J. Primary squamous cell carcinoma of the main hepatic bile duct. Can J Surg. 2008; 51(4):E85-6.

25. Blechacz B, Gores GJ. Cholangiocarcinoma: advances in pathogenesis, diagnosis, and treatment. Hepatology. 2008;48(1):308-21.

26. Nakanuma $Y$, Sato $Y$, Harada $K$, Sasaki $M, X u$ J, Ikeda $H$. Pathological classification of intrahepatic cholangiocarcinoma based on a new concept. World J Hepatol. 2010;2(12):419-27.

27. Yamashita Y, Takahashi M, Kanazawa S, Charnsangavej C, Wallace S. Hilar cholangiocarcinoma. An evaluation of subtypes with CT and angiography.ActaRadiol. 1992;33(4):351-5.

28. deGroen PC, Gores GJ, LaRusso NF, Gunderson LL, Nagorney DM. Biliary tract cancers. N Engl J Med. 1999;341(18):1368-78.

29. Wiggers JK, Ruys AT, Groot Koerkamp B, Beuers U, ten Kate FJ, van Gulik TM. Differences in immunohistochemical biomarkers between intra- and extrahepatic cholangiocarcinoma: a systematic review and meta-analysis. J GastroenterolHepatol. 2014;29(8):1582-94.

30. Ruys AT, Groot Koerkamp B, Wiggers JK, Klumpen HJ, ten Kate FJ, van Gulik TM. Prognostic biomarkers in patients with resected cholangiocarcinoma: a systematic review and meta-analysis. Ann Surg Oncol. 2014;21(2):487-500.

31. Tan FL, Ooi A, Huang D, Wong JC, Qian CN, Chao C, et al. p38delta /MAPK13 as a diagnostic marker for cholangiocarcinoma and its 
involvement in cell motility and invasion. Int J Cancer. 2010;126(10): 2353-61.

32. SB E. AJCC cancer staging handbook: from the AJCC cancer staging manual. 7th Edition. New York: Springer; 2010.

33. Mao K, Liu J, Sun J, Zhang J, Chen J, Pawlik TM, et al. Patterns and prognostic value of lymph node dissection for resected perihilar cholangiocarcinoma. J GastroenterolHepatol. 2016;31(2):417-26.

34. Rizvi S, Gores GJ. Pathogenesis, diagnosis, and management of cholangiocarcinoma. Gastroenterology. 2013;145(6):1215-29.

35. Jaiswal M, LaRusso NF, Burgart LJ, Gores GJ. Inflammatory cytokines induce DNA damage and inhibit DNA repair in cholangiocarcinoma cells by a nitric oxide-dependent mechanism. Cancer Res. 2000; 60(1):184-90.

36. Homayounfar K, Gunawan B, Cameron S, Haller F, Baumhoer D, Uecker $\mathrm{S}$, et al. Pattern of chromosomal aberrations in primary liver cancers identified by comparative genomic hybridization. Hum Pathol. 2009:40(6):834-42.

37. Kongpetch S, Jusakul A, Ong CK, Lim WK, Rozen SG, Tan P, et al. Pathogenesis of cholangiocarcinoma: From genetics to signalling pathways. Best Pract Res ClinGastroenterol. 2015;29(2):233-44

38. Rahnemai-Azar AA, Weisbrod AB, Dillhoff M, Schmidt C, Pawlik TM. Intrahepatic cholangiocarcinoma: current management and emerging therapies. Expert Rev GastroenterolHepatol. 2017.

39. Zhu AX, Borger DR, Kim Y, Cosgrove D, Ejaz A, Alexandrescu S, et al. Genomic profiling of intrahepatic cholangiocarcinoma: refining prognosis and identifying therapeutic targets. Ann SurgOncol. 2014; 21(12):3827-34

40. Kipp BR, Voss JS, Kerr SE, Barr Fritcher EG, Graham RP, Zhang L, et al. Isocitrate dehydrogenase 1 and 2 mutations in cholangiocarcinoma. Hum Pathol. 2012;43(10):1552-8.

41. Blechacz B, Komuta M, Roskams T, Gores GJ. Clinical diagnosis and staging of cholangiocarcinoma. Nat Rev GastroenterolHepatol. 2011;8(9):512-22.

42. Hadjis NS, Adam A, Gibson R, Blenkharn JI, Benjamin IS, Blumgart LH. Nonoperative approach to hilar cancer determined by the atrophyhypertrophy complex. Am J Surg. 1989;157(4):395-9.

43. Hann LE, Getrajdman GI, Brown KT, Bach AM, Teitcher JB, Fong Y, et al. Hepatic lobar atrophy: association with ipsilateral portal vein obstruction. AJR Am J Roentgenol. 1996;167(4):1017-21.

44. Anderson CD, Pinson CW, Berlin J, Chari RS. Diagnosis and treatment of cholangiocarcinoma. Oncologist. 2004;9(1):43-57.

45. Khan SA, Davidson BR, Goldin RD, Heaton N, Karani J, Pereira SP, et al. Guidelines for the diagnosis and treatment of cholangiocarcinoma: an update. Gut. 2012:61(12):1657-69.

46. Levy C, Lymp J, Angulo P, Gores GJ, Larusso N, Lindor KD. The value of serum CA 19-9 in predicting cholangiocarcinomas in patients with primary sclerosing cholangitis. Dig Dis Sci. 2005;50(9):1734-40.

47. Sinakos E, Saenger AK, Keach J, Kim WR, Lindor KD. Many patients with primary sclerosing cholangitis and increased serum levels of carbohydrate antigen 19-9 do not have cholangiocarcinoma. Clin Gastroenterol Hepatol. 2011;9(5):434-9 e1.

48. Rerknimitr R, Angsuwatcharakon P, Ratanachu-ek T, Khor CJ, Ponnudurai R, Moon JH, et al. Asia-Pacific consensus recommendations for endoscopic and interventional management of hilar cholangiocarcinoma. J GastroenterolHepatol. 2013:28(4):593-607.

49. Mansour JC, Aloia TA, Crane CH, Heimbach JK, Nagino M, Vauthey JN. Hilar cholangiocarcinoma: expert consensus statement. HPB (Oxford). 2015;17(8):691-9.

50. Baron TH, Harewood GC, Rumalla A, Pochron NL, Stadheim LM, Gores GJ, et al. A prospective comparison of digital image analysis and routine cytology for the identification of malignancy in biliary tract strictures.ClinGastroenterolHepatol. 2004;2(3):214-9.

51. Razumilava N, Gores GJ. Classification, diagnosis, and management of cholangiocarcinoma.Clin Gastroenterol Hepatol. 2013;11(1):13-21 e1; quiz e3-4

52. Moreno Luna LE, Kipp B, Halling KC, Sebo TJ, Kremers WK, Roberts $\mathrm{LR}$, et al. Advanced cytologic techniques for the detection of malignant pancreatobiliary strictures. Gastroenterology. 2006;131(4):1064-72.

53. Poruk KE, Pawlik TM, Weiss MJ. Perioperative Management of Hilar
Cholangiocarcinoma. J Gastrointest Surg. 2015;19(10):1889-99.

54. Bismuth $\mathrm{H}$, Corlette MB. Intrahepatic cholangioenteric anastomosis in carcinoma of the hilus of the liver.SurgGynecol Obstet. 1975; 140(2):170-8.

55. Jarnagin WR, Fong $\mathrm{Y}$, DeMatteo RP, Gonen M, Burke EC, Bodniewicz BJ, et al. Staging, resectability, and outcome in 225 patients with hilar cholangiocarcinoma. Ann Surg. 2001;234(4): 507-17; discussion 17-9.

56. Deoliveira ML, Schulick RD, Nimura Y, Rosen C, Gores G, Neuhaus $\mathrm{P}$, et al. New staging system and a registry for perihilar cholangiocarcinoma. Hepatology. 2011;53(4):1363-71.

57. de Jong MC, Hong SM, Augustine MM, Goggins MG, Wolfgang CL, Hirose K, et al. Hilar cholangiocarcinoma: tumor depth as a predictor of outcome. Arch Surg. 2011;146(6):697-703.

58. Aoba T, Ebata T, Yokoyama Y, Igami T, Sugawara G, Takahashi Y, et al. Assessment of nodal status for perihilar cholangiocarcinoma: location, number, or ratio of involved nodes. Ann Surg. 2013;257(4):718-25.

59. Kambakamba $P$, Linecker $M$, Slankamenac K, DeOliveira ML. Lymph node dissection in resectable perihilar cholangiocarcinoma: a systematic review. Am J Surg. 2015;210(4):694-701.

60. Rocha FG, Matsuo K, Blumgart LH, Jarnagin WR. Hilar cholangiocarcinoma: the Memorial Sloan-Kettering Cancer Center experience. J Hepatobiliary Pancreat Sci. 2010;17(4):490-6.

61. Zaydfudim VM, Clark CJ, Kendrick ML, Que FG, Reid-Lombardo $\mathrm{KM}$, Donohue JH, et al. Correlation of staging systems to survival in patients with resected hilar cholangiocarcinoma. Am J Surg. 2013;206(2):159-65

62. Buettner S, vanVugt JL, Gani F, Groot Koerkamp B, Margonis GA, Ethun CG, et al. A Comparison of Prognostic Schemes for Perihilar Cholangiocarcinoma. J Gastrointest Surg. 2016;20(10):1716-24

63. Groot Koerkamp B, Wiggers JK, Gonen M, Doussot A, Allen PJ, Besselink MG, et al. Survival after resection of perihilar cholangiocarcinoma-development and external validation of a prognostic nomogram. Ann Oncol. 2015;26(9):1930-5.

64. Nagino M, Ebata T, Yokoyama Y, Igami T, Sugawara G, Takahashi Y, et al. Evolution of surgical treatment for perihilar cholangiocarcinoma: a single-center 34 -year review of 574 consecutive resections. Ann Surg. 2013;258(1):129-40.

65. Connor S, Barron E, Wigmore SJ, Madhavan KK, Parks RW, Garden OJ. The utility of laparoscopic assessment in the preoperative staging of suspected hilar cholangiocarcinoma. J Gastrointest Surg. 2005; 9(4):476-80.

66. Weber SM, DeMatteo RP, Fong Y, Blumgart LH, Jarnagin WR. Staging laparoscopy in patients with extrahepatic biliary carcinoma. Analysis of 100 patients. Ann Surg. 2002;235(3):392-9.

67. Ruys AT, Busch OR, Gouma DJ, van Gulik TM. Staging laparoscopy for hilar cholangiocarcinoma: is it still worthwhile? Ann SurgOncol. 2011;18(9):2647-53.

68. Valero V, 3rd, Cosgrove D, Herman JM, Pawlik TM. Management of perihilar cholangiocarcinoma in the era of multimodal therapy. Expert Rev GastroenterolHepatol. 2012;6(4):481-95.

69. Launois B, Reding R, Lebeau G, Buard JL. Surgery for hilar cholangiocarcinoma: French experience in a collective survey of 552 extrahepatic bile duct cancers. J Hepatobiliary Pancreat Surg. 2000;7(2):128-34.

70. LaFemina J, Jarnagin WR. Surgical management of proximal bile duct cancers.Langenbecks Arch Surg. 2012;397(6):869-79.

71. Nimura Y, Hayakawa N, Kamiya J, Kondo S, Shionoya S. Hepatic segmentectomy with caudate lobe resection for bile duct carcinoma of the hepatic hilus. World J Surg. 1990;14(4):535-43; discussion 44.

72. de Jong MC, Marques H, Clary BM, Bauer TW, Marsh JW, Ribero $D$, et al. The impact of portal vein resection on outcomes for hilar cholangiocarcinoma: a multi-institutional analysis of 305 cases. Cancer. 2012;118(19):4737-47.

73. Bhardwaj N, Garcea G, Dennison AR, Maddern GJ. The Surgical Management of KlatskinTumours: Has Anything Changed in the Last Decade? World J Surg. 2015;39(11):2748-56.

74. Hemming AW, Reed AI, Fujita S, Foley DP, Howard RJ. Surgical management of hilar cholangiocarcinoma. Ann Surg. 2005;241(5): 
693-9; discussion 9-702.

75. Hasegawa S, Ikai I, Fujii H, Hatano E, Shimahara Y. Surgical resection of hilar cholangiocarcinoma: analysis of survival and postoperative complications. World J Surg. 2007;31(6):1256-63.

76. Nishio H, Nagino M, Nimura Y. Surgical management of hilar cholangiocarcinoma: the Nagoya experience. HPB (Oxford). 2005; 7(4):259-62.

77. Dumitrascu T, Chirita D, Ionescu M, Popescu I. Resection for hilar cholangiocarcinoma: analysis of prognostic factors and the impact of systemic inflammation on long-term outcome. J Gastrointest Surg. 2013;17(5):913-24.

78. Allen PJ, Reiner AS, Gonen M, Klimstra DK, Blumgart LH, Brennan $M F$, et al. Extrahepatic cholangiocarcinoma: a comparison of patients with resected proximal and distal lesions. HPB (0xford). 2008;10(5):341-6.

79. Matsuo K, Rocha FG, Ito K, D'Angelica MI, Allen PJ, Fong Y, et al. The Blumgart preoperative staging system for hilar cholangiocarcinoma: analysis of resectability and outcomes in 380 patients. J Am Coll Surg. 2012;215(3):343-55.

80. Abdalla EK. Portal vein embolization (prior to major hepatectomy) effects on regeneration, resectability, and outcome. J SurgOncol. 2010;102(8):960-7

81. Abdalla EK, Adam R, Bilchik AJ, Jaeck D, Vauthey JN, Mahvi D. Improving resectability of hepatic colorectal metastases: expert consensus statement. Ann Surg0ncol. 2006:13(10):1271-80.

82. Ribero D, Chun YS, Vauthey JN. Standardized liver volumetry for portal vein embolization. SeminInterventRadiol. 2008;25(2):104-9.

83. Farges 0, Belghiti J, Kianmanesh R, Regimbeau JM, Santoro R, Vilgrain V, et al. Portal vein embolization before right hepatectomy: prospective clinical trial. Ann Surg. 2003;237(2):208-17.

84. Sarmiento JM, Nagorney DM. Hepatic resection in the treatment of perihilar cholangiocarcinoma. SurgOncolClin N Am. 2002;11(4):893908, viii-ix.

85. Liu F, Li Y, Wei Y, Li B. Preoperative biliary drainage before resection for hilar cholangiocarcinoma: whether or not? A systematic review. Dig Dis Sci. 2011;56(3):663-72.

86. Tsai HM, Chuang CH, Lin XZ, Chen CY. Factors relating to the short term effectiveness of percutaneous biliary drainage for hila cholangiocarcinoma. World J Gastroenterol. 2009;15(41):5206-10.

87. Gouma DJ. Multicentre European study of preoperative biliary drainage for hilar cholangiocarcinoma (Br J Surg 2013; 100: 274283). Br J Surg. 2013;100(2):283-4.

88. Gomez D, Patel PB, Lacasia-Purroy C, Byrne C, Sturgess RP, Palmer $\mathrm{D}$, et al. Impact of specialized multi-disciplinary approach and an integrated pathway on outcomes in hilar cholangiocarcinoma. Eur $\mathrm{J}$ SurgOncol. 2014;40(1):77-84.

89. Kawashima $\mathrm{H}$, Itoh $\mathrm{A}$, Ohno $\mathrm{E}$, Itoh $\mathrm{Y}$, Ebata $\mathrm{T}$, Nagino $\mathrm{M}$, et al. Preoperative endoscopic nasobiliary drainage in 164 consecutive patients with suspected perihilar cholangiocarcinoma: a retrospective study of efficacy and risk factors related to complications. Ann Surg. 2013;257(1):121-7.

90. Grendar J, Grendarova P, Sinha R, Dixon E. Neoadjuvant therapy for downstaging of locally advanced hilar cholangiocarcinoma: a systematic review. HPB (Oxford). 2014;16(4):297-303.

91. Darwish Murad S, Kim WR, Harnois DM, Douglas DD, Burton J, Kulik LM, et al. Efficacy of neoadjuvant chemoradiation, followed by liver transplantation, for perihilar cholangiocarcinoma at 12 US centers. Gastroenterology. 2012;143(1):88-98 e3; quiz e14.

92. Rea DJ, Heimbach JK, Rosen CB, Haddock MG, Alberts SR, Kremers WK, et al. Liver transplantation with neoadjuvant chemoradiation is more effective than resection for hilar cholangiocarcinoma. Ann Surg. 2005;242(3):451-8; discussion 8-61.

93. Heimbach JK, Gores GJ, Nagorney DM, Rosen CB. Liver transplanta- tion for perihilar cholangiocarcinoma after aggressive neoadjuvant therapy: a new paradigm for liver and biliary malignancies? Surgery. 2006;140(3):331-4.

94. Gores GJ, Darwish Murad S, Heimbach JK, Rosen CB. Liver transplantation for perihilar cholangiocarcinoma. Dig Dis. 2013;31(1):126-9.

95. Takada T, Nimura Y, Katoh H, Nagakawa T, Nakayama T, Matsushiro T, et al. Prospective randomized trial of 5-fluorouracil, doxorubicin, and mitomycin $\mathrm{C}$ for non-resectable pancreatic and biliary carcinoma: multicenter randomized trial. Hepatogastroenterology. 1998;45(24): 2020-6.

96. Neoptolemos JP, Moore MJ, Cox TF, Valle JW, Palmer DH, McDonald $\mathrm{AC}$, et al. Effect of adjuvant chemotherapy with fluorouracil plus folinic acid or gemcitabine vs observation on survival in patients with resected periampullary adenocarcinoma: the ESPAC-3 periampullary cancer randomized trial. JAMA. 2012;308(2):147-56.

97. Horgan AM, Amir E, Walter T, Knox JJ. Adjuvant therapy in the treatment of biliary tract cancer: a systematic review and metaanalysis. J ClinOncol. 2012;30(16):1934-40.

98. Rea DJ, Rosen CB, Nagorney DM, Heimbach JK, Gores GJ. Transplantation for cholangiocarcinoma: when and for whom? SurgOncolClin N Am. 2009;18(2):325-37, ix.

99. Valle J, Wasan H, Palmer DH, Cunningham D, Anthoney A, Maraveyas A, et al. Cisplatin plus gemcitabine versus gemcitabine for biliary tract cancer. N Engl J Med. 2010;362(14):1273-81.

100. Valle JW, Furuse J, Jitlal M, Beare S, Mizuno N, Wasan H, et al. Cisplatin and gemcitabine for advanced biliary tract cancer: a metaanalysis of two randomised trials. Ann Oncol. 2014;25(2):391-8.

101. Agarwal R, Sendilnathan A, Siddiqi NI, Gulati S, Ghose A, Xie C, et al. Advanced biliary tract cancer: clinical outcomes with ABC-02 regimen and analysis of prognostic factors in a tertiary care center in the United States. J Gastrointest Oncol. 2016;7(6):996-1003.

102. Chen JS, Hsu C, Chiang NJ, Tsai CS, Tsou HH, Huang SF, et al. A KRAS mutation status-stratified randomized phase II trial of gemcitabine and oxaliplatin alone or in combination with cetuximab in advanced biliary tract cancer. Ann Oncol. 2015;26(5):943-9.

103. Malka D, Cervera P, Foulon S, Trarbach $T$, de la Fouchardiere C, Boucher E, et al. Gemcitabine and oxaliplatin with or without cetuximab in advanced biliary-tract cancer (BINGO): a randomised, open-label, non-comparative phase 2 trial. Lancet Oncol. 2014;15(8):819-28.

104. Ole Larsen F, Taksony Solyom Hoegdall D, Hoegdall E, Nielsen D. Gemcitabine, capecitabine and oxaliplatin with or without cetuximab in advanced biliary tract carcinoma. Acta Oncol. 2016;55(3):382-5.

105. Leone F, Marino D, Cereda S, Filippi R, Belli C, Spadi R, et al. Panitumumab in combination with gemcitabine and oxaliplatin does not prolong survival in wild-type KRAS advanced biliary tract cancer: A randomized phase 2 trial (Vecti-BIL study). Cancer. 2016;122(4): 574-81.

106. Lee J, Park SH, Chang HM, Kim JS, Choi HJ, Lee MA, et al. Gemcitabine and oxaliplatin with or without erlotinib in advanced biliary-tract cancer: a multicentre, open-label, randomised, phase 3 study. Lancet Oncol. 2012;13(2):181-8.

107. Valle JW, Wasan H, Lopes A, Backen AC, Palmer DH, Morris K, et al. Cediranib or placebo in combination with cisplatin and gemcitabine chemotherapy for patients with advanced biliary tract cancer (ABC-03): a randomised phase 2 trial. Lancet Oncol. 2015;16(8):96778.

108. Bekaii-Saab T, Phelps MA, Li X, Saji M, Goff L, Kauh JS, et al. Multi-institutional phase II study of selumetinib in patients with metastatic biliary cancers. J ClinOncol. 2011;29(17):2357-63.

109. Bridgewater J, Lopes A, Beare S, Duggan M, Lee D, Ricamara M, et al. A phase $1 b$ study of Selumetinib in combination with Cisplatin and Gemcitabine in advanced or metastatic biliary tract cancer: the ABC-04 study. BMC Cancer. 2016;16:153. 